\title{
Improvement of dry tropical rangelands in Hai- nan Island, China: 2. Evaluation of pasture grasses
}

\author{
DAVID L. MICHALK, FU NAN-PING, AND ZHU CHIN-MING
}

Authors are former director, former pasture technician, and production manager of Gaopoling Model Cattle Farm, Ba Suo, Dong Fang County, Hainan Island, People's Republic of China.

\begin{abstract}
During 1981-83, we studied 19 grasses for potential improvement of dry tropical (1,001 $\mathrm{mm}$ annual rainfall) rangelands in Hainan Island, China. The productivity and persistence of the grasses were tested on sandy $(<5 \mathrm{mg} / \mathrm{kg}$ available $P)$ and loam soils $(12-25 \mathrm{mg} / \mathrm{kg})$ under cutting in a randomized block design with plots split for sequential sowings in 1981, 1982, and 1983. Grass response to legume-fixed and nitrogen fertilizer was also assessed. Thirteen of the 19 grasses tested under cutting established satisfactorily (density $>5$ plants $/ \mathrm{m}^{2}$ ), but only 6 cultivars produced yields $>1.5$ metric tonne (t)/ha. Melinis minutiflora Beauv., Brachiaria decumbens Stapf. and Chloris gayana Kunth. yielded more than $1.5 \mathrm{t} / \mathrm{ha}$ in 3-year-old swards on both soils, whereas Panicum maximum Jacq. and Setaria sphacelata (Schum.) Stapf. ex Massey only performed well on fertile loam soil. Grass establishment was superior on sandy soil, but plant density did not correlate well with production which was higher on red loam soil due to better water-

\footnotetext{
The authors wish to thank Huang Zhen-Sheng, former manager of Gaopoling Farm, for providing facilities for the experimental program and the Pasture Production Team for assisting with the field work. The vital communication link provided by interpreters Deng Zhou-Lien and Yen Ren-Chang between Australian advisers and their Chinese counterparts is gratefully acknowledged. DLM also thanks other members of the Australian team at Gaopoling Farm, Dr. J.F. Ayres, and Mr. S.E. Dunn and NSW Agriculture Overseas project Director, Mr. G.D. Slennett, for their support and encouragement. The work was conducted under the auspices of the NSW-Guangdon Sister Government Agreement. The statistical advice provided by Ms. H. Nicol is also gratefully acknowledged.

Manuscript accepted 8 Nov. 1992.
}

holding capacity and nutrient status. Compatibility of these successful grasses with companion legumes was low with legumes contributing $<0.4 \mathrm{t} / \mathrm{ha}$ to total yield of 3-year-old $M$. minutiflora, $B$. decumbens and $P$. maximum swards, and having minimal effect on soil nitrogen. Nitrogen fertilizer $(50 \mathrm{~kg} \mathrm{~N} / \mathrm{ha} / \mathrm{yr}$ ) more than doubled grass production, but was profitable only where grass response exceeded grass/legume swards $>4 \mathrm{t} / \mathrm{ha}$. $S$. sphacelata was the only grass to form a stable mixture with companion legumes. [Macroptilium atropurpurem (D.C.) Urban and Stylosanthes guianensis (Aubl.) Sw.], which yielded more than $1.1 \mathrm{t} / \mathrm{ha}$ in 3-year-old swards on loam soil. This combination was recommended for improvement of loam soil rangelands. It is concluded from this study that range improvement with perennial grasses is confined to fertile soils, while direct broadcast of Stylosanthes legumes only into grazed native pastures is the practice recommended for improvement of infertile sandy soil until persistent low $P$ tolerant grasses are found for the dry tropics.

Key Words: China, dry tropical, low phosphorus soil, Setaria sphacelata, $\mathbf{N}$ response, legume

Known as "wastelands", the rangelands of dry tropical Hainan Island, China, are dominated by low-producing grasses $(<2.2$ $\mathrm{DM} / \mathrm{ha} / \mathrm{hr}$ ) of poor quality (Michalk and Fu 1988). Recent studies have identified suitable legumes for improvement of major soil types in western Hainan which significantly increase carrying capacity and beef output (Michalk et al. 1985, Michalk and Fu 
1988, Michalk et al. 1993). There is concern regarding the longterm stability of native pastures oversown with introduced legumes. Experience in the dry tropics of Australia indicates that increased grazing capacity of legume-improved rangeland may lead to pasture instability (Andrew 1988) caused by a sudden decline in the native perennial grass component (Winks et al. 1974) and invasion by annual species (Gillard and Fisher 1978). Perennial grasses are desirable components of range vegetation because they provide production stability, prevent ingress of woody weeds, and commence growth on less precipitation than do annual legumes and grasses (Norman 1967).

Like northern Australia, dominant native grasses of dry tropical Hainan are either of poor quality or readily damaged by heavy grazing. Heavy grazing has caused retrogression of rangelands in Hainan from bunchgrass-dominant swards through secondary transitional communities to prostrate, low-producing, grazingtolerant grasses such as Chrysopogon aciculatus Trin. and Axonopus compressus (Swartz) Beauv. While domesticated local grasses such as Miscanthus floridulus Warb. ex K. Schum \& Lauterb., Digitaria sanguinalis (L.) Scop., Sorghum propingnum (Kunth.) Hitchcock, Hemarthria compressa R. Br., and Pennisetum polystachyon Schult. have been cultivated and utilized for many years in the southern provinces (Hong 1985, Hwang et al. 1986), Chinese scientists and state farm managers realized that the introduction of grasses and legumes offers a faster and more efficient means of range improvement in south China (Hong 1985).

Planned introduction of pasture grasses and legumes began in the early 1950's, and under the supervision of the Chinese Academy of Agricultural Science, universities, and provincial agricultural departments, imported species have been tested and popularized to varying degrees in the tropical areas of China. Test plots of some Australian cultivars established in 1974 at the Livestock Research Institute of Guangxi Province first highlighted the potential of pasture species used commercially in northern Australia for improvement of the tropical and subtropical zone of China (Hong 1985). While many of the introduced grasses (e.g., Panicum maximum Jacq., Pennisetum purpurem Schum. and forage sorghums) have performed well in the wet tropical zone, little is known about the productivity and persistence of introduced grasses in the dry tropical regions of south China.

In this second paper focusing on improvement of dry tropical rangelands in China, we report results of a 3-year (1981-1983) experimental program undertaken to evaluate grasses on 2 soil types at Gaopoling Model Cattle Farm (Dong Fang County) in western Hainan Island. Aims of the study were: (1) to assess the growth potential of some Australian grasses in dry tropical China; and (2) to determine grass response to legume-fixed and fertilizer nitrogen.

The results reported here were used in conjunction with legume evaluations also undertaken at Gaopoling Farm (Michalk et al. 1993) to formulate grass-legume mixtures for use under grazing in western Hainan.

\section{Material and Methods}

Site

The location, climate, soil types, and range vegetation of Gaopoling Model Cattle Farm $\left(19^{\circ} 09^{\prime} \mathrm{N} ; 108^{\circ} 68^{\prime} \mathrm{W}\right)$ are described in detail by Michalk et al. (1993). These conditions are representative of the 162,000 ha set aside in dry tropical Hainan Island for improvement for range-based cattle production.

\section{Plot Design and Culture}

To select grasses to improve range forage, an experiment was conducted on replicated (3) plots $(3 \mathrm{~m} \times 21 \mathrm{~m})$ of 19 tropical grasses (Table 1) arranged in a randomized block design split in time for sequential sowings on sandy and red loam soils. Grasses were sown by hand at recommended seeding rates (Table 1) and lightly raked into weed-free, cultivated seedbeds in 1981 (4 August), 1982 (12 June), and 1983 (14 July).

The loam site for the 1981 sowing was newly cleared of softwood scrub, stick-raked, and ploughed between April and planting. Loam sites for the 1982 and 1983 sowings and all sandy sites were scrub-free, open grassland. Germination tests conducted prior to sowing showed seed of all grasses to be of good quality (Table 1).

\section{Treatments}

To test compatibility with legumes and contribution of legumefixed nitrogen to grass production, plots were split for the 1981 sowing to include: (1) grass only; (2) grass + a mixture of Macroptilium atropurpureum (DC) Urban cv Siratro, Stylosanthes hamata (L.) Taub. cv Verano, and S. scabra Vog. cv Seca sown at $6 \mathrm{~kg} / \mathrm{ha}$ on sandy soil, and siratro and S. guianensis (Aubl.) Sw. cv Cook at the same rate on loam soil, and (3) grass + fertilizer nitrogen $(50 \mathrm{~kg}$

Table 1. Name, sowing rate, germination percentage, and first-year establishment of tropical grasses tested at Gaopoling Farm, $1981-1983$.

\begin{tabular}{|c|c|c|c|c|c|}
\hline \multirow[b]{2}{*}{ Botanical name } & \multirow[b]{2}{*}{ Common name \& cultivar } & \multirow[b]{2}{*}{ Sowing rate } & \multirow[b]{2}{*}{ Germination } & \multicolumn{2}{|c|}{ Establishment ${ }^{1}$} \\
\hline & & & & Sand & Loam \\
\hline Melinis minutiflora Beauv. & Molasses grass & 4 & 56 & $46 a$ & $23 a *$ \\
\hline Setaria sphacelata (Schum.) Stapf ex Massey & Setaria cv Kazungula & 5 & 53 & $18 b c$ & $6 \mathrm{~cd} *$ \\
\hline Brachiaria decumbens Stapf. & Signal grass cv Basilisk & 6 & 40 & 9def & $7 \mathrm{~cd} *$ \\
\hline B. mutica (Forsk) Stapf & Para grass & 6 & 31 & $12 \mathrm{de}$ & $9 \mathrm{~cd}$ \\
\hline Chloris gayana Kunth. & Rhodes grass cv Samford & 6 & 48 & $22 b$ & $8 \mathrm{bcd} *$ \\
\hline C. gayana & Rhodes grass cv Callide & 6 & 33 & 8ef & 9 bcd \\
\hline Panicum maximum Jacq. & Guinea grass cv Hamil & 6 & 37 & $18 \mathrm{bd}$ & $13 b *$ \\
\hline P. maximum Jacq. var. trichoglume Eyles & Green panic cv Petrie & 6 & 23 & $8 \mathrm{ef}$ & $4 d *$ \\
\hline Cenchrus ciliaris $\mathrm{L}$. & Buffel grass cv Gayndah & 4 & 53 & $6 f$ & 8 bcd \\
\hline C. ciliaris & Buffel grass cv Biloela & 4 & 28 & $18 \mathrm{bc}$ & $11 b c *$ \\
\hline Paspalum plicatulum Michx. & Brownseed grass cv Bryan & 6 & 32 & $7 e f$ & $4 d *$ \\
\hline P. plicatulum & Brownseed grass cv Rodd's Bay & 6 & 68 & $16 \mathrm{~cd}$ & $5 \mathrm{~d} *$ \\
\hline Urochlora mosambicensis (Hack.) Dandy & Sabi grass cv Nixon & 6 & 29 & $4 f$ & $7 \mathrm{~cd} *$ \\
\hline Pennistem clandestinum Hochst. ex Chiov. & Kikuyu cv Whittet & 2 & 48 & $\mathbf{F}$ & $\mathrm{F}$ \\
\hline Paspalum dilatatum Poir. & Dallis grass & 10 & 63 & $\mathbf{F}$ & $\mathrm{F}$ \\
\hline$P$. notatum Flugge & Bahia grass & 4 & 80 & $\mathbf{F}$ & $\mathbf{F}$ \\
\hline Axonopus affinis A. & Carpet grass & 3 & 98 & $\mathrm{~F}$ & $\mathbf{F}$ \\
\hline Sorghum almum Parodi & Columbus grass & 3 & 55 & $\mathrm{~F}$ & $\mathbf{F}$ \\
\hline Cenchrus setigerus Vahl. & Birdwood grass & 4 & 36 & $\mathbf{F}$ & $\mathbf{F}$ \\
\hline
\end{tabular}

Grass density means within soil type followed by the same letter are not significantly different at $P<0.05$; ${ }^{*}$ indicates a significant difference ( $P<0.05$ ) in grass density due to soil type; 'Establishment for grass/legume plots (Treatment 2) averaged over 3 sowings $(1981,1982,1983$. $F=$ failed to establish. 
$\mathrm{N} / \mathrm{ha} / \mathrm{yr}$ ). Treatments 1 and 3 were sown in the 1981 , but only grass/ legume mixtures (Treatment 2) were sown in 1982 and 1983.

All plots were fertilized with local Grade 4 superphosphate ( 28 $\mathrm{kg} \mathrm{P} / \mathrm{ha}$ ) at sowing and top-dressed each year (14 kg P/ha). Legume seed was inoculated and pelleted prior to sowing.

\section{Sampling}

In November of each establishment year, grass and legume establishment were estimated by counting plants in two $0.5-\mathrm{m}^{2}$ quadrats/plot. Dry matter yield was assessed by harvesting with hand shears the entire plot $(3 \mathrm{~m} \times 21 \mathrm{~m})$ or subplot $(3 \mathrm{~m} \times 7 \mathrm{~m})$ at the end of the wet (December) and dry (May) seasons each year. Harvested material was weighed in the field, and subsamples taken to determine dry matter content and botanical composition. Only "wet season" data for grass/legume plots (Treatment 2) were used to assess grass performance as "dry season" growth was negligible. All yields are expressed in metric tonnes $(t) /$ ha.

\section{Statistical Analyses and Experimental Design}

Analyses of variance split in time were set up in the Genstat program (Payne et al. 1988) to analyze density and production data from the randomized block design for establishment year performance of sown grasses and companion legumes in the 3 sequential sowings with soil types (2), establishment years (3), and species (13) as main effects. Least significant differences based on error terms from the appropriate stratum of the analyses of variance were used to differentiate between significant and nonsignificant means.

Similar analyses were used to test significance of grass and legume yield in 1- (sequential sowings in 1981, 1982, and 1983); $2-(1981$ sowing cut in 1982, and 1982 sowing cut in 1983); and 3-(1981 sowing cut in 1983) year-old pasture swards. A linear regression model with fitted terms for year, soil type, pasture age, species, and all significant $(P<0.05)$ second and third order interactions was used to predict yield of sward components and verify analyses of variance. The high degree of variability in grass $\left(R^{2}=\right.$ $0.94)$, legume $\left(R^{2}=0.95\right)$ and total $\left(R^{2}=0.95\right)$ yields explained by these models indicated that there was no confounding between sites and years within soil types due to pooling data in the analysis of variance. Linear and nonlinear regressions were also used to examine relationships between species performance, rainfall, plant density, and age of pasture.

Analyses of responses of selected sown grasses to legume- and fertilizer-nitrogen were undertaken on both soils. This analysis included soil type (2), species (6), and nitrogen treatments (3) as main effects (Fig. 3).

\section{Results}

\section{A. Establishment Year}

\section{Plant Density}

Thirteen grasses established successfully with average density $>5$ plants $/ \mathrm{m}^{2}$ (Table 1 ). Soil type affected $(P<0.05)$ grass density with $60 \%$ more plants measured at the end of the first wet season in 1-year-old swards on sandy soil compared with red loam soil (Table 1) in all 3 sowings.

Molasses grass (see Table 1 for botanical names) established best on both soil types, producing dense, vigorous stands. After molasses grass, setaria, rhodes grass, guinea grass, and buffel grass established well on sandy soil with similar density (18 to 22 plant $/ \mathrm{m}^{2}$ ), but on loam soil the number of guinea and Biloela buffel seedlings was higher than the other grasses (Table 1). Despite differences in length of growing season and rainfall (Table 2), there was no significant effect of year of sowing on establishment
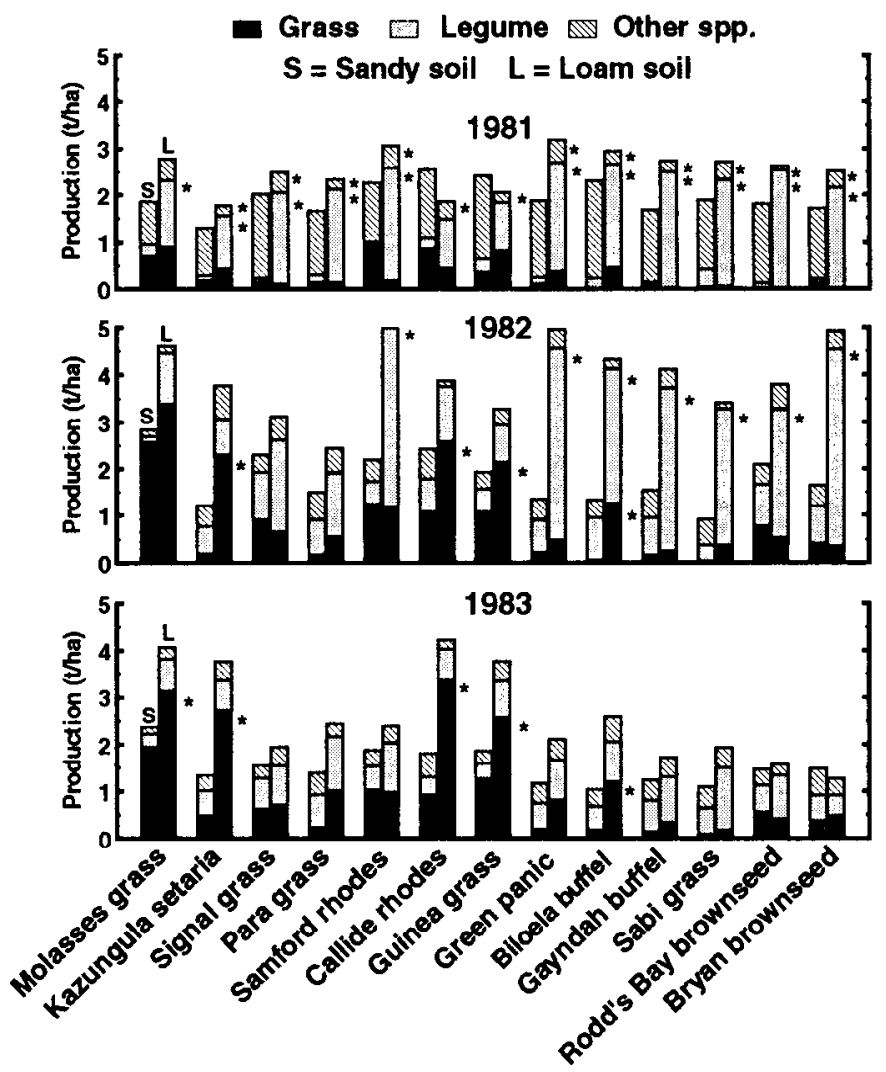

${ }^{*}$ and ${ }^{* *}$ indicates significant differences in legume or grass yield due to soil type at $P<0.05$ and $P<0.01$

Fig. 1. Establishment year production (t DM/ha) of grass/legume mixtures sown on sand and loam soils at Gaopoling Farm (1981-83).

density. Some grasses (e.g., green panic, Gayndahl buffel, columbus grass, and sabi grass) were present only as weak plants, many of which failed to survive the first dry season. Grasses which failed to establish in 1981 also failed at subsequent sowings.

Legume density and stylo:siratro ratio differed $(P<0.05)$ with soil type and year of sowing. Legume density was $36 \%$ higher with a greater proportion of siratro on loam soil (5:7 stylo: siratro; 11.5 plants $\left./ \mathrm{m}^{2}\right)$ whereas stylos established better on sandy soils $(7: 2$ stylo:siratro; 8.5 plants $/ \mathrm{m}^{2}$ ). Companion legumes did not affect grass establishment or vice versa. There was no correlation between grass and legume density $\left(R^{2}=0.13\right)$.

\section{Production in Establishment Year}

Molasses grass produced highest establishment year yield followed by rhodes grass, guinea grass, and setaria, which all produced mean yields $>0.9 \mathrm{t} /$ ha (Fig. 1), except for setaria grown on sandy soil $(0.3 \mathrm{t} / \mathrm{ha})$. Grass production in l-year-old stands was affected by year of establishment with lower yield $(P<0.01)$ recorded in 1981 (Fig. 1). This was due to lower than average rainfall and the short growing season caused by late sowing (4 August). Grasses did not respond uniformly to more favourable growth conditions experienced in 1982 and 1983 (Fig. 1). Production of grasses which yielded $<0.5 \mathrm{t} /$ ha at the first sowing was similar at subsequent sowing, where grasses with mean yield $>0.5$ $t /$ ha in 1981 produced between 0.6 and $1.9 \mathrm{t} /$ ha more dry matter in the 1982 and 1983 sowings (Fig. 1).

Soil type did not affect establishment year yield of grasses with mean yield $<1 \mathrm{t} /$ ha, except for Gayndah buffel which produced more dry matter $(P<0.05)$ on loam soil (Fig. 1). Grasses with mean 
production $>1 \mathrm{t} / \mathrm{ha}$ (molasses, setaria, guinea grass, and Callide rhodes) were consistently more productive when grown on loam soil (Fig. 1). Correlation between grass yield (Fig. 1) and rainfall received during the sowing to harvest period accounted for most of the variation in production between establishment years on loam soil $\left(R^{2} 0.98\right)$, but explained less variation on sandy soil $\left(R^{2} 0.85\right)$ where nutrient deficiencies were more pronounced (Michalk et al. 1993).

For grass species which are more suited to regions with annual rainfall $<1,000 \mathrm{~mm}$ (e.g., setaria and rhodes grass), fertility limited growth most on sandy sites as rainfall explained $<25 \%$ of year-toyear variation in first-year production. In contrast, rainfall accounted for $90 \%$ of yield variation on sandy soil of grasses which perform best in $>1,300 \mathrm{~mm}$ rainfall zones (e.g., guinea grass and green panic). For all species, first-year grass yield correlated poorly with plant density. Despite higher establishment density on sandy soil (Table 1), production of sown grasses was similar or superior on loam soil, depending on growth conditions and length of growing season (Table 2). Grass yield was not affected by legume density in establishment year.

Table 2. Significant main effects for establishment year production (t DM/ha) of grass/legume mixtures sown on and loam soils at Gaopoling Farm (1981-1983).

\begin{tabular}{lllcc}
\hline \hline \multirow{2}{*}{$\begin{array}{l}\text { Main } \\
\text { Effect }\end{array}$} & Comparison & Grass & Legume & Other spp. \\
\hline Soil type & Sand & $0.54 \mathrm{a}$ & $0.45 \mathrm{~b}$ & $0.76 \mathrm{a}$ \\
& Loam & $0.98 \mathrm{a}$ & $1.74 \mathrm{a}$ & $0.35 \mathrm{~b}$ \\
Year & 1981 & $0.31 \mathrm{~b}$ & $1.04 \mathrm{~b}$ & $0.90 \mathrm{a}$ \\
& 1982 & $0.96 \mathrm{a}$ & $1.55 \mathrm{a}$ & $0.40 \mathrm{~b}$ \\
& 1983 & $1.01 \mathrm{a}$ & $0.69 \mathrm{~b}$ & $0.37 \mathrm{~b}$ \\
Sown grass & Molasses grass & $2.11 \mathrm{a}$ & $0.64 \mathrm{~b}$ & $0.34 \mathrm{~b}$ \\
& Signal grass & $0.53 \mathrm{def}$ & $1.09 \mathrm{ab}$ & $0.62 \mathrm{a}$ \\
& Setaria & $1.06 \mathrm{bcd}$ & $0.63 \mathrm{~b}$ & $0.52 \mathrm{ab}$ \\
& Para grass & $0.38 \mathrm{f}$ & $1.20 \mathrm{a}$ & $0.57 \mathrm{a}$ \\
& Callide rhodes & $1.55 \mathrm{~b}$ & $0.70 \mathrm{~b}$ & $0.55 \mathrm{ab}$ \\
& Samford rhodes & $0.94 \mathrm{cde}$ & $1.44 \mathrm{a}$ & $0.51 \mathrm{ab}$ \\
& Guinea grass & $1.37 \mathrm{bc}$ & $0.62 \mathrm{~b}$ & $0.56 \mathrm{a}$ \\
& Biloela buffel & $0.37 \mathrm{f}$ & $1.44 \mathrm{a}$ & $0.64 \mathrm{a}$ \\
& Gayndah buffel & $0.53 \mathrm{def}$ & $1.26 \mathrm{a}$ & $0.64 \mathrm{a}$ \\
& Green panic & $0.16 \mathrm{f}$ & $1.41 \mathrm{a}$ & $0.60 \mathrm{a}$ \\
& Sabi grass & $0.13 \mathrm{f}$ & $1.29 \mathrm{a}$ & $0.57 \mathrm{a}$ \\
& Rodd's Bay brownseed & $0.42 \mathrm{f}$ & $1.29 \mathrm{a}$ & $0.51 \mathrm{ab}$ \\
& Bryan brownseed & $0.30 \mathrm{f}$ & $1.37 \mathrm{a}$ & $0.60 \mathrm{a}$
\end{tabular}

Main effect means within parameters followed by the same letter are not significantly different at $P<0.05$.

\begin{tabular}{lccr}
\hline \multicolumn{4}{c}{ Sowing to harvest } \\
\hline & 1981 & 1982 & 1983 \\
\hline Growth period (days) & 130 & 172 & 159 \\
Rainfall (mm) & 458 & 879 & 1022 \\
\hline
\end{tabular}

Unlike sown grasses, soil type affected $(P<0.05)$ first year legume production with sandy soil producing only $9 \%$ to $60 \%$ of yield measured on loam soil, depending on year of establishment and companion grass (Fig. 1; Table 2). Highest first year legume yield was measured in the 1982 sowing on both soil types and lowest in 1981 on sandy soil and in 1983 on loam soil (Fig. 1). A higher $(P<0.01)$ proportion of native grass measured in the 1981 sowing may explain poor legume growth on sandy soil, but there is no apparent reason for the $50 \%$ reduction of legume yield on loam soil for the 1983 sowing (Fig. 1). Aggressive grasses (eg. setaria, guinea, molasses, and Callide rhodes) also affected legume performance by reducing yield by $1 \mathrm{t} /$ ha, particularly on loam soil (Fig. 1) where grass growth was not limited by soil fertility.

\section{B. Total Production}

Molasses grass was the most productive grass tested (Fig. 2 , Table 3) with yield averaged over soil types and production years exceeding that of signal grass, guinea grass, Callide rhodes grass, and setaria by at least $0.9 \mathrm{t} / \mathrm{ha} / \mathrm{yr}$. Overall, grass performance was affected $(P<0.05)$ by soil type (Fig. 2$)$ with loam soil producing $45 \%$ more dry matter than sandy soil (Table 3 ). However, grass

Table 3. Significant main effects for establishment year production (t $\mathrm{DM} / \mathrm{ha}$ ) and composition of 1-, 2-, and 3-year-old grass/legume mixtures sown in sand and loam soils at Gaopoling Farm (1981-1983).

\begin{tabular}{lllll}
\hline Main & & \multicolumn{3}{c}{ Parameter } \\
\cline { 2 - 5 } Effect & Comparison & Grass & Legume & Other spp. \\
\hline Soil type & Sand & $1.04 \mathrm{~b}$ & $0.77 \mathrm{~b}$ & $0.55 \mathrm{~b}$ \\
& Loam & $1.50 \mathrm{a}$ & $1.49 \mathrm{a}$ & $0.65 \mathrm{a}$ \\
Year & 1-year-old & $0.76 \mathrm{c}$ & $1.08 \mathrm{~b}$ & $0.56 \mathrm{~b}$ \\
& 2-year-old & $1.73 \mathrm{a}$ & $1.60 \mathrm{a}$ & $0.77 \mathrm{a}$ \\
& 3-year-old & $1.31 \mathrm{~b}$ & $0.73 \mathrm{c}$ & $0.47 \mathrm{c}$ \\
Sown grass & Molasses grass & $2.95 \mathrm{a}$ & $0.81 \mathrm{ef}$ & $0.20 \mathrm{e}$ \\
& Signal grass & $2.05 \mathrm{~b}$ & $0.90 \mathrm{def}$ & $0.53 \mathrm{~cd}$ \\
& Setaria & $1.65 \mathrm{c}$ & $0.99 \mathrm{cdef}$ & $0.49 \mathrm{~cd}$ \\
& Para grass & $0.95 \mathrm{~d}$ & $1.00 \mathrm{cde}$ & $0.38 \mathrm{~d}$ \\
& Callide rhodes & $1.91 \mathrm{bc}$ & $1.01 \mathrm{cde}$ & $0.61 \mathrm{bc}$ \\
& Samford rhodes & $1.67 \mathrm{c}$ & $1.13 \mathrm{~cd}$ & $0.63 \mathrm{bc}$ \\
& Guinea grass & $1.93 \mathrm{bc}$ & $0.72 \mathrm{f}$ & $0.47 \mathrm{~cd}$ \\
& Biloela buffel & $0.54 \mathrm{efg}$ & $1.58 \mathrm{ab}$ & $0.88 \mathrm{a}$ \\
& Gayndah buffel & $0.39 \mathrm{~g}$ & $1.45 \mathrm{ab}$ & $0.93 \mathrm{a}$ \\
& Green panic & $0.46 \mathrm{fg}$ & $1.45 \mathrm{ab}$ & $0.63 \mathrm{bc}$ \\
& Sabi grass & $0.33 \mathrm{~g}$ & $1.21 \mathrm{bc}$ & $0.78 \mathrm{ab}$ \\
& Rodd's Bay brownseed & $0.83 \mathrm{de}$ & $1.26 \mathrm{c}$ & $0.44 \mathrm{~d}$ \\
& Bryan brownseed & $0.82 \mathrm{def}$ & $1.22 \mathrm{bc}$ & $0.85 \mathrm{a}$ \\
\hline
\end{tabular}

Main effect means within parameters followed by the same letter are not significantly different at $P<0.05$.

response was not uniform: production of 6 grasses was affected significantly by soil type whereas 7 species (Samford rhodes, Callide rhodes, signal, Gayndahl buffel, green panic, Bryan brownseed, and sabi) produced similar yields on both soil types. Where there was a significant difference in production due to soil type, yield of grasses was superior on loam soil, except for Rodd's Bay brownseed which produced $0.85 \mathrm{t} / \mathrm{ha} / \mathrm{yr}$ more dry matter on sand soil (Fig. 2).

Grass yield for 1-year-old pastures on both soil types was generally less than half production of 2-year-old stands (Fig. 2), but the production pattern over the whole measurement period differed with species and soil type. For sandy soil, there was no difference between grass production in 2- and 3-year-old stands, except for molasses grass and signal grass where 3 -year-old swards yielded less $(P<0.05)$ than 2-year-old swards.

For loam soil, 5 of the 6 best grasses yielded less $(P<0.05)$ as 3-year-old than as 2-year-old pastures (Fig. 2) due mainly to a wildfire which burnt the 1981 sown site in late August 1983. Guinca grass, signal grass, and setaria recovered best with yield still exceeding $2.4 \mathrm{t} / \mathrm{ha}$ (Fig. 2) in 3-year-old swards. The production pattern over time for grasses with yield $>0.5 \mathrm{t} / \mathrm{ha} / \mathrm{yr}$ was either parabolic (Year 1<Year 2>Year 3) or logarithmic (Year 1<Year 2 = Year 3). There was no consistent relationship between age and yield of grasses on loam soil with mean 3-year yield $<0.5 \mathrm{t} / \mathrm{ha} / \mathrm{yr}$.

For both soil types, grass and legume yields in 2-and 3-year old pastures were poorly related to plant density measured in either the current or previous season. Despite higher density at establishment and in subsequent years, production of sown grass on sandy soil was only $50 \%$ that of loam soil in 2-year-old stands (1.2 vs $2.2 \mathrm{t} / \mathrm{ha}$ ).

Dominated by siratro, loam soil legume production $(1.5 \mathrm{t} / \mathrm{ha} / \mathrm{yr})$ was twice that of the stylo-dominate legume component of sandy soil (Fig. 2). Despite difference in overall production levels, a 

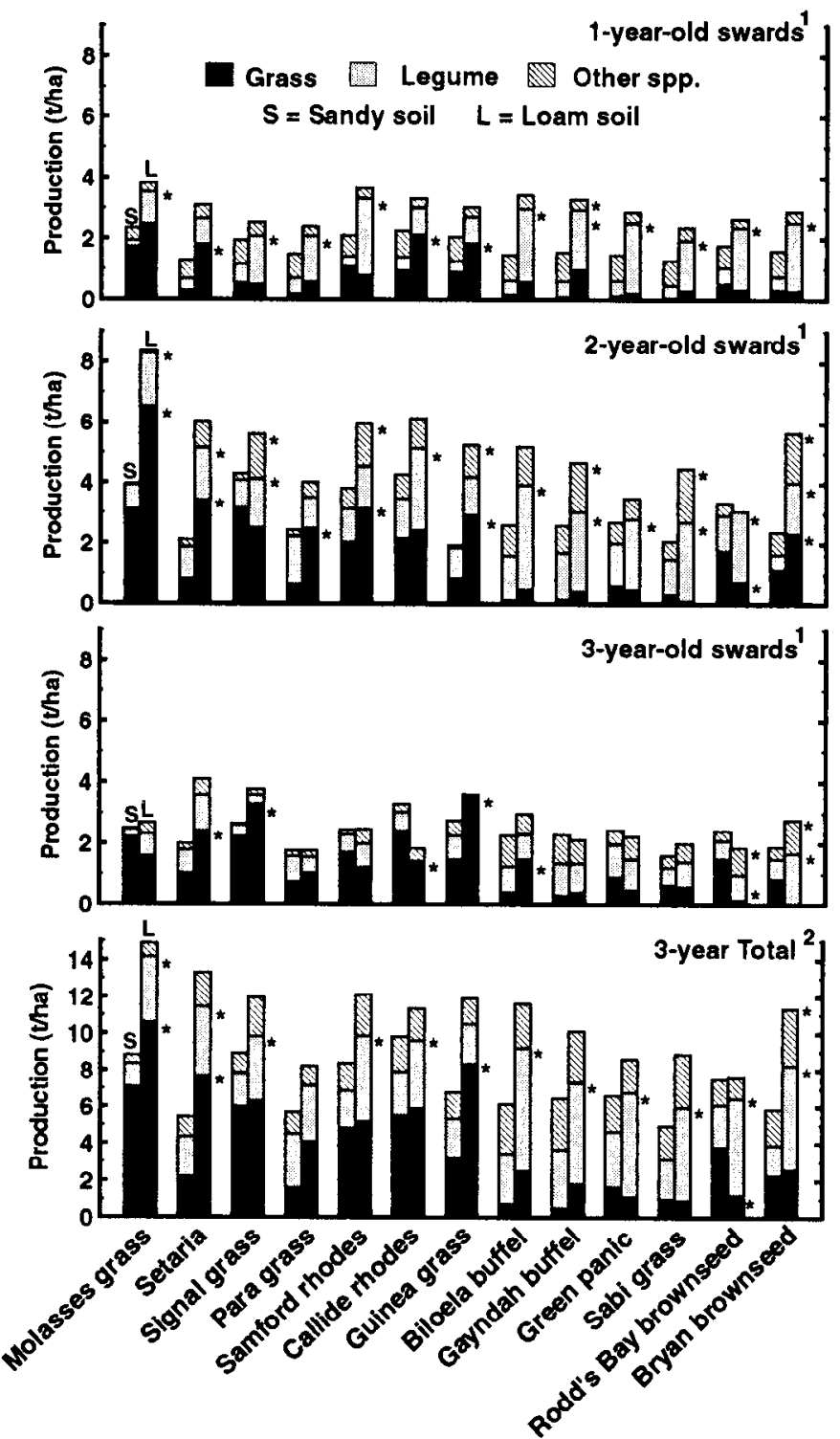

Fig. 2. Yield and composition of 1-, 2-, and 3-year-old grass pastures sown on sand and loam soils at Gaopoling Farm (1981-83).

similar parabolic pattern of legume production was evident on both soil types with more legume present in 2-year-old grass/legume mixtures. However, for loam soil this may be due to the 1983 wildfire which reduced legume to the same level as sandy soil.

Legume growth was suppressed $(P<0.05)$ by grasses such as molasses grass, signal grass, and setaria, but legume production on loam still exceeded sandy soil legume yield for each grass treatment by 0.5 to $1.3 \mathrm{t} / \mathrm{ha} / \mathrm{yr}$ (Fig. 2), except for guinea grass, which responded vigorously to nutrients released by the 1983 wildfire and reduced legume yield to zero on loam soil. The proportion of legume present accounted for more than $25 \%$ of the total sward production over 3 years, except for grass species with total 3-year grass yield $>8 \mathrm{t} /$ ha on loam and $>5.5 \mathrm{t} /$ ha on sandy soil (Fig. 2).

Native bunch grasses on loam soil were more productive than stoloniferous species on sandy soil, but they did not compete as vigorously with sown grasses and legumes. In general, yield of sown grasses and legumes correlated inversely with yield of volunteer species on sandy soil $\left(R^{2} 0.46\right)$, but were not related on loam soil ( $R^{2}$ 0.24). On sandy soil, competition was most intense in establishing pasture where native grasses accounted for $44 \%$ of total production, but declined in 2- and 3-year-old pastures
$(<18 \%)$ when the more erect sown grasses and legumes effectively shaded the prostrate natives. On loam soil, the contribution of native bunch grasses was highest $(1.1 \mathrm{t} /$ ha averaged over all grass / legume mixtures) in 2-year-old pastures.

Molasses grass most effectively controlled growth of native grasses, reducing their contribution to $<0.1 \mathrm{t} /$ ha on both soil types by the second year of production. Signal grass and guinea grass were the next most competitive grasses which reduced native grass contribution to $<0.2 \mathrm{t} /$ ha by the third year of production.

In general, total production followed a parabolic pattern with 2-year-old pastures producing significantly more dry matter than 1- or 3-year-old swards. Due to superior performance of sown grasses and legumes, total production on loam soil was higher $(P<0.05)$ than sandy soil in most treatments (Fig. 2). The largest species $X$ soil type interaction occurred with setaria where loam soil plots produced an additional $7.8 \mathrm{t} / \mathrm{ha} / 3-\mathrm{yr}$ above sandy soil production (Fig. 2).

\section{Response to Nitrogen}

Response of selected 2-year-old grass swards (1981 sowing) to legume- and fertilizer-nitrogen are shown in Figure 3 for both soil types. Nitrogen had little impact on establishment year yield, and results for 3-year-old swards were skewed by the 1983 wildfire on loam soil.

Overall, urea ( $50 \mathrm{~kg} \mathrm{~N} / \mathrm{ha}$ ) applied at the start of the wet season improved grass production by $68 \%$ on sand soil and doubled yield on red loam compared with grasses grown without companion legumes and nitrogen fertilizer (Fig. 3, Table 4). However, species showed differential responses to nitrogen and soil type. On loam soil, all grasses yielded more $(P<0.05)$ when fertilized with urea (Treatment 3 ), whereas on the sandy site, only molasses grass and signal grass responded significantly (Fig. 3). This indicated that other factors such as soil moisture and other soil nutrients limited grass response on sandy soil.

There was no difference in grass yield between grass only (Treatment 1) and grass/legume plots (Treatment 2) to indicate active transfer of legume-fixed nitrogen to sown or indigenous companion grasses on either soil type (Table 4) even in treatments where legume yield exceeded $2 \mathrm{t} / \mathrm{ha}$.

Volunteer native grasses failed to respond to nitrogen applied to sandy soil $(0.7,0.6$, and $0.8 \mathrm{t} /$ ha for Treatments 1,2 , and 3 , respectively), but increased yield by 0.5 to $1.3 \mathrm{t} /$ ha on loam soil in

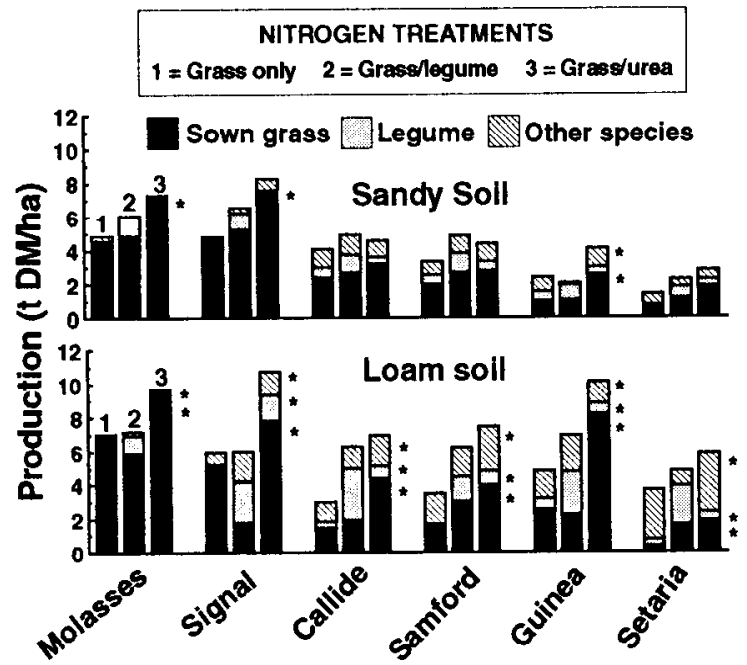

Fig. 3. Response of selected 2-year-old grass swards to legume- and fertilizer-nitrogen when grown on sand and loam soils at Gaopoling Farm. 
Table 4. Significant main effects for response of selected grasses to legume and fertilizer nitrogen.

\begin{tabular}{llccc}
\hline \hline \multirow{2}{*}{$\begin{array}{l}\text { Main } \\
\text { Effect }\end{array}$} & Comparison & Grass & Legume & Other spp. \\
\hline Soil type & Sand & $2.92 \mathrm{a}$ & $0.56 \mathrm{~b}$ & $0.70 \mathrm{~b}$ \\
& Loam & $3.59 \mathrm{a}$ & $1.16 \mathrm{a}$ & $1.48 \mathrm{a}$ \\
N-treatment & Grass only & $2.48 \mathrm{~b}$ & $0.37 \mathrm{~b}$ & $1.01 \mathrm{~b}$ \\
& Grass/legume & $2.59 \mathrm{~b}$ & $1.61 \mathrm{a}$ & $0.97 \mathrm{~b}$ \\
& Grass/urea & $4.69 \mathrm{a}$ & $0.59 \mathrm{~b}$ & $1.29 \mathrm{a}$ \\
Sown grass & Molasses grass & $6.54 \mathrm{a}$ & $0.41 \mathrm{~b}$ & $0.09 \mathrm{~d}$ \\
& Signal grass & $5.29 \mathrm{~b}$ & $0.91 \mathrm{a}$ & $0.85 \mathrm{c}$ \\
& Callide rhodes & $2.68 \mathrm{c}$ & $0.79 \mathrm{a}$ & $1.52 \mathrm{a}$ \\
& Samford rhodes & $2.69 \mathrm{c}$ & $1.04 \mathrm{a}$ & $1.25 \mathrm{~b}$ \\
& Guinea grass & $2.94 \mathrm{c}$ & $0.74 \mathrm{a}$ & $1.50 \mathrm{a}$ \\
& Setaria & $1.26 \mathrm{~d}$ & $0.96 \mathrm{a}$ & $1.19 \mathrm{~b}$ \\
\hline
\end{tabular}

Main effect means within parameters followed by the same letter are not significantly different at $P<0.05$.

all sown grass plots except guinea grass and molasses grass, which suppressed native grass growth (Fig. 3).

\section{Discussion and Management Implications}

The initial evaluation criteria for grasses introduced to dry tropical environments include: (1) ability to establish and produce under variable rainfall regimes; (2) ability to survive a protracted dry season; and, (3) compatability with companion legumes (Edye 1975). Only 6 grasses fulfilled these requirements by producing mean yields $>1.5 \mathrm{t} /$ ha. Soil type was an important determinant of grass adaptation and yield. Molasses grass, signal grass, and guinea grass yield exceeded $1.5 \mathrm{t} / \mathrm{h}$ a as 3-year-old swards on both soil types, but only the latter 2 responded significantly to the higher soil fertility and produced superior yield on loam soil. Setaria failed on sandy soil, but produced $2.4 \mathrm{t} /$ ha in 3-year-old stands on loam soil whereas Callide rhodes and Rodd's Bay performed better on sandy soil.

These evaluation results were used to formulate grass/legume mixtures for improvement of sandy and red loam rangelands in western Hainan. For pasture development on red loam soil, a mixture of Graham stylo and Siratro (Michalk et al. 1993) combined with guinea grass, signal grass or setaria is recommended for drilling into prepared seedbeds. Adaptation to lower rainfall and cooler temperature regimes enabled setaria to make significant growth on "unseasonable rainfall" during the cooler dry season, and make it the preferred grass for red loam even though it yielded less than either signal grass or guinea grass in this experiment.

Subsequent development of 515 ha of setaria-based pasture at Gaopoling Farm (Michalk and Dunn 1984) demonstrated that setaria can be successfully grown on red loam soil using low fertilizer inputs ( $28 \mathrm{~kg} \mathrm{P} /$ ha / 3-years; no nitrogen). These pastures have remained highly productive with siratro still contributing $40 \%$ of the dry matter after 8 years of grazing (Zhu Chin-Ming, unpublished data). Setaria has also proved to be a vaulable grass for improvement of acid soil areas below 1,000 m altitude in subtropical Guangdong (Michalk and Ryan 1989), Fujian (Wu et al. 1986), Guangxi (Michalk 1988), and Yunnan (Bruce-Smith et al. 1990) provinces.

A mixture of stylos (Seca, Verano, and/or Graham), either broadcast directly into native rangeland or combined with rhodes grass or signal grass on rough disked seedbeds are recommended improvement procedures for sandy soil. However, there are indications that these sown grasses may lack persistence, particularly if grazing management is poor. For example, while rhodes grass performed well on both soil types in this study, subsequent observations in commercial sowings indicate that the commonly reported pattern of rapid early colonization but lack of long-term persistence (Anning 1982) is also true for the 2 cultivars tested at Gaopoling Farm. Similarly, signal grass is unlikely to survive years in which the onset of the wet season is delayed (probability of 1 in 7 years).

Failure of buffel grass and sabi grass in this dry tropical zone of Hainan indicates their intolerance of low soil fertility and poor competitiveness with native grass and companion legumes, a result also noted by Anning (1982) in northern Queensland. While the superphosphate rate $(28 \mathrm{~kg} \mathrm{P} / \mathrm{ha})$ used in the present study has proved to be sufficient to maintain legume-based pastures on sandy soil for at least 3 years (Michalk et al. 1985, Michalk and Fu 1988), higher $P$ inputs may be required to establish and improve performance of grasses from these genera.

Other studies at Gaopoling Farm indicate that a doubling of the superphosphate rate will increase buffel grass to $1 \mathrm{t} /$ ha in the establishment year on sandy soil (D.L. Michalk, unpublished data). This has also been observed in verano stylo-sabi grass pastures in northern Australia where sabi grass only becomes dominant with high superphosphate applications (McIlvor 1984). Additional studies are needed to specify initial and maintenance phosphorus requirements of sown grasses in south China, particularly for phosphorus infertile sands.

As a "pioneer" species to provide quick cover in establishment year, molasses grass may be sown with these mixtures on either soil type. With time, however, more strongly perennating, grazingresistant, and fire-tolerant grasses take over to form a stable pasture which is more acceptable to cattle. Molasses grass may also be used in scrub control to provide rapid fuel build-up prior to burning and ensure a hot fire to exact maximum damage to shrubs (Humphreys 1978). Scrub encroachment is a major problem for range improvement on red loam soil (Colman and Wolfe 1987).

Brownseed grass was initially recommended for sandy soils in Hainan (Michalk et al. 1985), but commercial experiences in Queensland (Anning 1977) and more recently in China (Colman and Wolfe 1987) indicate that this grass should not be shown because it is often too competitive even for the perennial stylos and has low acceptability to cattle (Whiteman et al. 1985) unless heavily fertilized with nitrogen (Yet 1980). However, even when abundant forage is available, beef output on brownseed grass pastures is very low (Whiteman et al. 1985). Further, in the present study, brownseed grass did not recover from the 1983 wildfire.

Poor compatibility with companion legumes is a major concern with some of the successful grasses, and careful grazing management may be required to maintain legume component above $40 \%$, the proportion desired for high cattle production (Bryan and Evans 1973). With legume content $<0.4 \mathrm{t} /$ ha in 3-year-old swards of molasses grass, signal grass, and guinea grass (loam soil only), contribution of companion legume to soil nitrogen was minimal. Further, the parabolic production pattern of molasses grass and signal grass with time on sandy soil is indicative of productivity losses described by Hutton (1979) as grass dominant pastures become progressively nitrogen deficient.

In contrast, setaria formed a stable mixture on loam soil with siratro/stylo yield exceeding $1.1 \mathrm{t} / \mathrm{ha}$ by the third season of production. Slower establishment of setaria appears to favour the associated legumes, particularly siratro, but the long-term stability of setaria/ legume association depends on the legume chosen, grazing management, and fertilizer policy (Hacker and Jones 1969).

The inadequacy of legumes to provide sufficient nitrogen for companion grass growth was highlighted by the comparison of grass-legume swards with grasses fertilized with nitrogen, particuarly on loam soil where moisture was less restrictive than on sandy soil. Molasses grass, signal grass, and guinea grass produced between 3.7 and $6 \mathrm{t} /$ ha when fertilized with nitrogen. Assuming a value for pasture dry matter of Yuan $0.05 / \mathrm{kg}$ DM (\$US $1=$ Yuan 
5.5) and nitrogen fertilizer cost of $Y 3.27 / \mathrm{kg} \mathrm{N}$ plus $\mathrm{Y} 16 /$ ha for application (D.L. Michalk, unpublished data), the use of $50 \mathrm{~kg}$ $\mathrm{N} / \mathrm{ha} / \mathrm{yr}$ in the present study would be profitable only where grass response exceeded $4 \mathrm{t} / \mathrm{ha} / \mathrm{yr}$.

Lack of grass response to sown legumes was probably due to a low level of available legume-fixed nitrogen caused by poor Year 1 legume growth $(0.4 \mathrm{t} / \mathrm{ha}$ sand; $1.2 \mathrm{t} / \mathrm{ha}$ loam $)$ and not to a failure of legumes to nodulate. The lack of response of legumes to applied nitrogen supports this conclusion. Based on Henzell's (1968) finding that legume-fixed nitrogen (LFN) available to companion grass can be estimated by the equation: $L F N=0.8 \times 1.5$ legume DM $\times 2.5 \% \mathrm{~N}$, only 12 (sand) to 36 (loam) $\mathrm{kg} / \mathrm{ha}$ of LFN was available to grasses at the start of the second wet season. This is similar to estimates reported by Wetselaar (1967) for first year Townsville stylo ( $S$. humilis H.B.K.) pastures in dry monsoonal Australia. In subsequent years, however, Townsville stylo fixed more than $80 \mathrm{~kg} \mathrm{~N} /$ ha/year (Wetselaar 1967). Other studies at Gaopoling Farm have also demonstrated the value of sown legume on companion grass production in established swards (Fu and Michalk, unpublished data).

Fire can also have a significant effect on grass-legume balance, with fire generally favouring perennial grasses. Some introduced grasses such as guinea grass tolerate burning, whereas others like molasses grass are destroyed by fire. Recovery of molasses grass after burning in this study suggests that the wildfire on loam soil was not a hot fire. However, the legume component was reduced significantly by fire due mainly to poor post-fire recovery of Cook stylo, a result also reported by Michalk et al. (1993).

The results of this evaluation study indicate that the use of introduced grasses such as setaria will be mainly confined to red loam soils where existing vegetation (including scrub) can be removed by cultivation, and where acceptable grass production is possible with minimal phosphorus inputs. However, range improvement on sandy soil is confined to low-cost introduction of legumes, especially stylos, into burnt native pasture until more persistent, low phosphorus-tolerant grasses are found.

Grasses not included in the present studies which warrant testing in Hainan Island include Andropogon gayanus Kunth. (gamba grass); Bothriochloa insculpta (Rendle) Schweick (creeping blue grass); and Brachiaria humidicola (Hochst. ex A. Rich.) A. Camus, which have both shown compatibility with recommended legumes, disease resistance, and adaption to a wide range of soil types in northern Australia (Anning 1982) and South America (Hutton 1979).

\section{Literature Cited}

Andrew, M.H. 1988. Rangeland ecology and research in tropical northwest Australia in relation to the intensifying management of the beef cattle industry. p. 688-690. In: Panjab Singh, Vinod Shankar and A.K. Srivastava (eds.), Proc. 3rd Int. Rangeland Congress. Range Manage. India, Jhansi, India.

Anning, P. 1977. A study of the effects of sown companion grasses on the persistence of naturalized Townsville stylo (Stylosanthes humilis) at Lilyvale-Cape York Peninsula 1969-1975. Agr. Branch Rep. P-6-77, October, 1977, Queensland Dep. Primary Industry.

Anning, P. 1982. Evaluation on introduced grass species for pastures in the dry tropics of north Queensland. Trop. Grassl. 16:136-145.

Bryan, W.W., and T.R. Evans. 1973. Effect of soils, fertilizers and stocking rates on pastures and beef production on the Wallum of south-eastern Queensland. 2. Liveweight change and beef production. Aust. J. Exp. Agr. Anim. Husb. 13:530-536.

Bruce-Smith, J.R., Yang Guo-Rong, Huang Bi-Zhi, and Li Ji-Xin. 1989. Preliminary rate of growth curves for legume based improved pastures in the mid-altitude region of Yunan Province of southern China, $p$. 455-456. In: Proc. XVI Internat. Grassl. Congress. Assoc. Francaise pour la Production Fourragere, Nice, France.
Colman, R.L., and E.C. Wolfe. 1987. Pasture development on acid soils in North Guangdong Province: Project review, Overseas Proj. Sec.. New South Wales Agr. \& Fisheries, p. 24.

Edye, L.A. 1975. A comparison of twenty-seven introduced grasses in two dry-tropical environments in northern Queensland. Aust. J. Exp. Agr. Anim. Husb. 15:788-794.

Gillard, P., and M.J. Fisher. 1978. The ecology of Townsville stylo-based pastures in Northern Australia, p. 340-352. In: J.R. Wilson (ed.), Plant relations in pastures. CSIRO, Melbournc, Aust.

Hacker, J.B., and R.J. Jones. 1969. The Setaria sphacelata complex-A review. Trop. Grassl. 3:13-34.

Henzell, E.F. 1968. Sources of nitrogen for Queensland pastures. Trop. Grassl. 2:1-17.

Hong, Fu-Zeng, 1985. Studies on the tropical and subtropical pasture resources and their exploitation prospects in China. Trop. Agr. Res. 18:1-8.

Humphreys, L.R. 1978. Tropical pastures and forage crops. Intermed. Trop. Agr. Ser., Longman Group, Ltd., England.

Hutton, E.M. 1979. Problems and successes of legume-grass pastures, especially in tropical Latin America, p. 81-93. In: A.P. Sanchez and L.E. Tergas (eds.), Pasture production in acid soils of the tropics. Centro Internacional de Agricultura Tropical, Cali, Columbia.

Hwang, Miao-Yang, Wun Lan-Xiang, and Zhang Ching-Zhe. 1986. The main varieties of forages and their evaluation in southern China, $p$. 76-79. In: G.J. Blair, D.A. Ivory and T.R. Evans (eds.), Forages in Southeast Asia and South Pacific Agriculture. Workshop held at Cisarue, Indonesia, 19-23 August 1985. Aust. Centre for Int. Agr. Res.

McIvor, J.G. 1984. Phosphorus requirements and responses of tropical pasture species: native and introduced grasses, and introduced legumes. Aust. J. Exp. Agr. Anim. Husb. 24:370-378.

Michalk, D.L. 1988. I. Introduction to grassland resources of Guangxi. II. NSW-Guangxi Co-operation: Some possibilities, Overseas Proj. Sec., New South Wales Agr. \& Fisheries, p. 12.

Michalk, D.L., and S.E. Dunn. 1984. Pasture development and cattle management at Gaopoling Model Cattle Farm: Summary of achievements and recommendations for further development, Final Rep. to Agr. Bur. of Guangdong Province, Overseas Proj. Sec., New South Wales Agr. \& Fisheries, p. 146.

Michalk, D.L., and Fu Nan-Ping. 1988. Verano stylo: A useful legume for range improvement in the dry tropics of Hainan Island, China, p. 345-349. In: Panjab Singh, Vinod Shankar and A.K. Srivastava (eds.), Proc. 3rd Int. Rangeland Congr. Range Manage. Soc. India, Jhansi, India.

Michalk, D.L., and W.J. Ryan. 1989. A programme for soil improvement, pasture development and cattle management for acid infertile soils in Shaoguan Prefecture", Final Rep. to Agr. Bur. of Guangdong Province, Proj. Sec., New South Wales Agr. \& Fisheries, p. 140.

Michalk, D.L., Fu Nan-Ping, and Zhu Chin-Ming. 1993. Improvement of dry tropical rangelands in Hainan Island, China: 1. Evaluation of pasture legumes. J. Range Manage. 46:257-265.

Michalk, D.L., J.F. Ayres, Fu Nan-Ping, and Zhu Chin-Ming. 1985. Range improvement in tropical China: Gaopoling Model Cattle Farm, p. 1329-1331. In: T. Okubo (ed.-in-ch.) Proc. XV Int. Grassl. Congr. The Sc. Coun. of Jap. and the Jap. Soc. Grassl. Sc., Kyoto, Japan.

Norman, M.J.T. 1967. Companion grasses for Townsville lucerne at Katherine, N.T. J. Aust. Inst. Agr. Sci. 33:14-22.

Payne, R.W., and Committee. 1988. Genstat 5 reference Manual", Oxford Univ. Press, Oxford, England.

Wetselaar, R. 1967. Estimation of nitrogen fixation by four legumes in a dry monsoonal area of north-western Australia. Aust. J. Exp. Agr. Anim. Husb. 7:518-522.

Whiteman, P.C., Halim N. Ridzwan, B.W. Norton, and J.W. Hales. 1985. Beef production from three tropical grasses in south-eastern Queensland. Aust. J. Exp. Agr. 25:481-488.

Winks, L., F.C. Lamberth, K.W. Moir, and P.M. Pepper. 1974. Effect of stocking rate and fertilizer on the performance of steers grazing Townsville Stylo-based pastures in north Queensland. Aust. J. Exp. Agr. Anim. Husb. 15:146-154.

Wu, W.E., H.Q. Chen, X.N. Dong, and M.X. Liu. 1986. Introduction of Setaria ancepts cv Kazungula into Fujan. Fujian Agr. Sci. \& Tech. 2:28-30. (In Chinese). 